\title{
MASERASI ALKALI DARI BATANG PISANG (Musa paradisiaca) MENGGUNAKAN PELARUT AQUADEST
}

\section{ALKALI MASERATION FROM BANANA STEM (Musa paradisiaca) USING AQUADEST AS SOLVENT}

\author{
Lilis Sukeksi, Patima Valentina Haloho*, Masniar Sirait \\ Departemen Teknik Kimia, Fakultas Teknik, Universitas Sumatera Utara, \\ Jalan Almamater, Medan, 20155, Indonesia \\ *Email: halohopatima@gmail.com
}

\begin{abstract}
Abstrak
Tujuan penelitian ini yaitu untuk menentukan waktu penyerapan alkali dari batang pisang secara semibatch dan batch. Pada penelitian ini maserasi semibatch adalah proses leaching yang digunakan untuk mendapatkan besar waktu yang dibutuhkan pelarut untuk menyerap alkali pada abu batang pisang. Sedangkan maserasi sistem batch adalah proses leaching yang digunakan untuk mendapatkan besar waktu yang dibutuhkan pelarut mencapai titik jenuh (berhenti menyerap). Teknik pengumpulan data dalam penelitian ini adalah: penyiapan sampel dan pengeringan batang pisang, proses pengabuan (pirolisis) batang pisang, proses maserasi abu batang pisang secara semibatch dan batch, serta penentuan kadar alkali dengan metode titrasi. Dari hasil penelitian dapat disimpulkan bahwa batang pisang berpotensi dijadikan sebagai sumber alkali karena kandungan kalium $\left(\mathrm{K}_{2} \mathrm{O}\right)$ dan natrium $\left(\mathrm{Na}_{2} \mathrm{O}\right)$ pada abu batang pisang masing-masing sebesar 36,19\% dan 13,99\%. Kadar air dan rendemen abu batang pisang masing-masing sebesar 78,6\% dan 17,7\%. Waktu pelarut jenuh untuk sistem semibatch diperoleh selama 72 jam, sementara untuk sistem batch diperoleh waktu selama 12 hari. Normalitas ekstrak alkali pada percobaan maserasi semibatch dan batch masih mengalami peningkatan normalitas. Dimana pada rasio abu batang pisang/ pelarut berturut-turut sebesar 1 gram / $25 \mathrm{ml} ; 2$ gram / $25 \mathrm{ml} ; 3$ gram/ $25 \mathrm{ml}$; dan 4 gram / $25 \mathrm{ml}$ masing-masing memiliki nilai normalitas yang masih mengalami kenaikan dari 0,219 N menjadi 0,567 N; 0,407 N menjadi 0,891 N; 0,578 N menjadi 1,315 N; dan 0,819 $\mathrm{N}$ menjadi 1,345 N. Rendemen ekstrak alkali tertinggi diperoleh pada rasio abu batang pisang / pelarut 1 gram / $25 \mathrm{ml}$ yaitu sebesar $52,37 \%$.
\end{abstract}

Kata Kunci : alkali, batang pisang, maserasi, semibatch, batch

\begin{abstract}
The purpose of this research is to determine the time of alkali absorption from banana stem in semibatch and batch. In this study maceration maseration is a leaching process used to obtain the time required for solvent to absorb alkali in banana stem ash. While the batch system maseration is a leaching process used to obtain the time required for the solvent to reach saturation point (stop absorbing). Data collection techniques in this research are: sample preparation and drying of banana stem, banana stalking process banana stem, brazing ash process of banana stem in semibatch and batch, and determination of alkaline content by titration method. From result of research can be concluded that banana stem potentially serve as source of alkali because potassium $\left(\mathrm{K}_{2} \mathrm{O}\right)$ and sodium $\left(\mathrm{Na}_{2} \mathrm{O}\right)$ content in banana ash sticks respectively $36,19 \%$ and $13,99 \%$. Water content and yield of banana ash sticks were $78.6 \%$ and $17.7 \%$, respectively. The time for the semibatch system is obtained in 72 hours, while for the batch system was obtained in 12 days. Normalities of alkali extracts in semibatch and batch maceration still increased. Where in the ratio of banana stem ash/solvent is $1 \mathrm{gram} / 25 \mathrm{ml} ; 2 \mathrm{gram} / 25$ $\mathrm{ml} ; 3$ gram / $25 \mathrm{ml}$; and 4 gram / $25 \mathrm{ml}$ respectively had a normality value that still increased from $0.219 \mathrm{~N}$ to $0.567 \mathrm{~N} ; 0.407 \mathrm{~N}$ to $0.891 \mathrm{~N} ; 0.578 \mathrm{~N}$ to $1,315 \mathrm{~N}$; and $0.819 \mathrm{~N}$ to $1,345 \mathrm{~N}$. The highest permeated alkali yield was obtained ratio (banana stem ash/ solvent) 1 gram / $25 \mathrm{ml}$ of $52.37 \%$.
\end{abstract}

Keywords: alkali, banana stem, maceration, semibatch, batch

\section{Pendahuluan}

Pohon pisang (Musa paradisiaca) adalah tanaman buah herbal yang berasal dari kawasan Asia Tenggara (termasuk Indonesia) [11]. Batang pisang merupakan limbah dari hasil panen pisang yang sudah tua. Perbandingan bobot segar antara batang, daun dan buah pisang berturut-turut adalah $63 \%, 14 \%$, dan $23 \%$ [10]. Keberadaan batang pisang yang melimpah cenderung menimbulkan polusi lingkungan, seperti menimbulkan bau tidak sedap, merusak pemandangan, dan menjadi sarang larva serangga.

Di zaman yang serba modern ini, gaya hidup sudah mulai berubah. Isu pola hidup sehat menjadi tren yang banyak diperbincangkan yaitu mulai menuju pola hidup kembali ke alam (back to nature). Sehingga banyak produk alami yang menjadi pilihan konsumen seperti sabun alami, 
shampo alami, dan pasta gigi alami. Untuk menghasilkan produk tersebut dibutuhkan bahanbahan alami seperti alkali alami yang diekstrak dari tanaman.

Mengingat besarnya potensi kalium pada batang pisang, maka perlu dilakukan penelitian tentang maserasi alkali dari batang pisang. Alasan pemilihan metode maserasi karena mempunyai banyak keuntungan dibandingkan dengan metode leaching lainnya. Keuntungan utama metode maserasi yaitu, prosedur dan peralatan yang digunakan sederhana, hanya dibutuhkan bejana perendam, relatif hemat karena pelarut yang digunakan ialah air dan tidak merusak struktur dari abu yang diekstrak karena tanpa pemanasan [7] sehingga dapat dengan mudah diimplementasikan dikalangan masyarakat.

\section{Teori}

Tanaman pisang merupakan tanaman semak berbatang semu. Hampir semua bagian tanaman pisang memiliki fungsi dan kegunaan bagi manusia. Akan tetapi tidak semua masyarakat yang memanfaatkan keseluruhan bagian tanaman pisang terutama pada bagian batang. Batang pisang yang tidak dipakai biasanya langsung dibuang sehingga menjadikan batang pisang itu sendiri menjadi limbah.

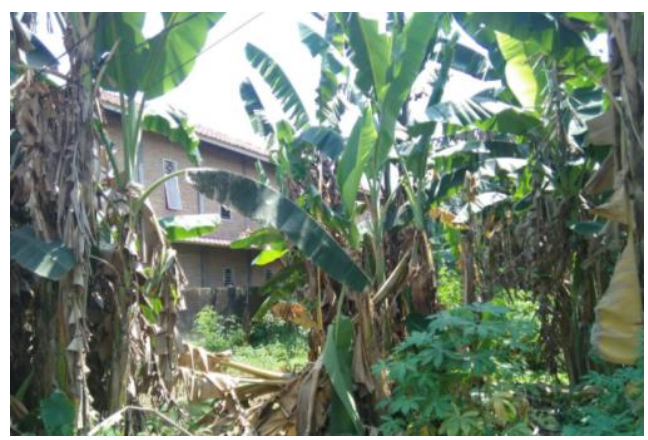

Gambar 1. Kebun Pisang di Daerah Padang Bulan

Batang pisang dapat dijadikan sumber berbagai mineral karena memiliki persentase berat abu sebesar 14\%. Komposisi mineral yang terdapat dalam abu batang pisang yaitu kalium, kalsium, magnesium, silikon dan fosfor [9]. Pemanfaatan batang pisang sebagai sumber alkali dapat dilakukan dengan 3 tahapan, yang pertama ialah pengurangan kadar air batang pisang, kedua proses pirolisis (pengabuan) batang pisang dengan menggunakan muffle furnace, dan yang ketiga proses maserasi abu batang pisang.

Abu merupakan bahan anorganik yang tidak dapat dibakar dari sumber bahan bakar yang tersisa setelah melalui pembakaran sempurna dan mengandung fraksi mineral dari biomassa tersebut [9]. Bahan-bahan organik dalam proses pembakaran akan terbakar tetapi komponen anorganiknya tidak, karena itulah disebut sebagai kadar abu. Kandungan abu dan komposisinya tergantung pada jenis bahan dan cara pengabuannya [1]. Metode pengabuan (dekarbonisasi) dibagi menjadi dua bagian yaitu pengabuan kering dan pengabuan basah. Metode pengabuan cara kering banyak dilakukan untuk analisis kadar abu. Caranya adalah dengan mendestruksi komponen organik, contoh dengan suhu tinggi di dalam suatu tanur (furnace) pengabuan, tanpa terjadi nyala api sampai terbentuk abu berwarna putih keabuan dan berat tetap (konstan) tercapai. Oksigen yang terdapat di dalam udara bertindak sebagai oksidator. Oksidasi komponen organik dilakukan pada suhu tinggi 500-600 ${ }^{\circ} \mathrm{C}$. Pengabuan basah menggunakan oksidator-oksidator kuat (asam kuat) [12].

Istilah maserasi berasal dari bahasa latin "mecerare" yang artinya mengairi, melunakkan, merupakan cara ekstraksi yang paling sederhana. Maserasi adalah ekstraksi suatu bahan menggunakan pelarut dengan pengadukan pada suhu ruang. Waktu maserasi berbeda-beda, masing-masing mencantumkan sekitar 4-10 hari. Pengadukan dilakukan agar cepat mendapat kesetimbangan antara bahan yang diekstraksi dalam bagian sebelah dalam sel dengan yang masuk ke dalam cairan. Keadaan diam tanpa pengadukan selama maserasi menyebabkan turunnya perpindahan bahan aktif [4]. Proses pengerjaan dilakukan dengan cara merendam serbuk simplisia dalam pelarut. Pelarut akan menembus dinding sel dan masuk ke dalam rongga sel yang mengandung zat aktif. Zat aktif akan larut karena adanya perbedaan konsentrasi antara larutan zat aktif di dalam sel dengan di luar sel, maka larutan yang terpekat akan didesak keluar. Peristiwa tersebut berulang sehingga terjadi kesetimbangan konsentrasi antara larutan di luar sel dan di dalam sel. Keuntungan dari metode maserasi yaitu posedur dan peralatannya sederhana [7].

\section{Metodologi Penelitian BahanBaku dan Peralatan}

Bahan yang digunakan dalam penelitian ini adalah batang pisang yang diperoleh dari jl. Abdul Hakim Kampung Susuk Padang Bulan, Medan, aquadest, $\mathrm{HCl}$, Phenolphtalein, dan larutan buffer basa.

Alat yang digunakan meliputi furnace, cawan porselen, erlenmeyer, desikator, corong gelas, kertas saring, gelas ukur, batang pengaduk, statif dan klem, buret, pipet tetes, neraca analitik, $\mathrm{pH}$ meter, dan beaker glass 


\section{Prosedur Pembuatan Abu}

Adapun prosedur pembuatan abu batang pisang adalah batang pisang segar dijemur dibawah sinar matahari selama 7 hari. Kemudian setelah kering batang pisang dipotong-potong dan di masukkan dalam cawan lalu susun cawan ke dalam muffle furnace. Diatur waktu furnace 3 jam dengan suhu $550{ }^{\circ} \mathrm{C}$. Setelah itu dinginkan abu batang pisang dalam desikator. Lalu timbang hasil pembakaran menggunakan neraca digital.

\section{Prosedur Maserasi Abu Batang Pisang Maserasi dengan Sistem Semibatch}

Maserasi sistem semibatch adalah proses leaching yang digunakan untuk mendapatkan besar waktu yang dibutuhkan pelarut untuk menyerap alkali pada abu batang pisang. Prosedur maserasi abu batang pisang dengan sistem semibatch adalah dengan menggunakan rasio 1 gram abu batang pisang/ $25 \mathrm{ml}$. Ditimbang abu batang pisang sebanyak 16 gram dimasukkan kedalam erlenmeyer $(500 \mathrm{ml})$. kemudian ditambahkan pelarut aquadest sebanyak $400 \mathrm{ml}$ kedalam Erlenmeyer dan tutup tabung dengan alluminium foil. Diamkan pada suhu kamar tanpa diberi perlakuan pengadukan. Setelah 12 menit diambil sampling larutan sebanyak $20 \mathrm{ml}$. Lalu analisa nilai normalitas ekstrak alkali batang pisang. Lakukan penyamplingan sampel pada selang waktu 24 jam, 36 jam, 48 jam, 60 jam, 72 jam dan 84 jam masing-masing sebanyak $20 \mathrm{ml}$. Penyamplingan dihentikan sampai normalitas ekstrak alkali telah konstan. Dilakukan perlakuan yang sama dengan variasi rasio 2 gram abu batang pisang/ $25 \mathrm{ml} ; 3$ gram abu batang pisang/ $25 \mathrm{ml}$; dan 4 gram abu batang pisang/ $25 \mathrm{ml}$.

\section{Maserasi dengan Sistem Batch}

Maserasi sistem batch adalah proses leaching yang digunakan untuk mendapatkan besar waktu yang dibutuhkan pelarut mencapai titik jenuh (berhenti menyerap). Prosedur maserasi abu batang pisang dengan sistem batch adalah dengan menggunakan rasio 1 gram abu batang pisang/ $25 \mathrm{ml}$. Ditimbang abu batang pisang sebanyak 32 gram dimasukkan kedalam erlenmeyer (1000 ml). Lalu ditambahkan pelarut aquadest sebanyak $800 \mathrm{ml}$ kedalam erlenmeyer dan tutup tabung dengan alluminium foil. Diamkan selama 3 hari. Saring dengan kertas saring kemudian ukur volume filtrat alkali lalu ambil $20 \mathrm{ml}$ dari ekstrak yang diperoleh untuk dianalisa normalitasnya. Tambahkan abu batang pisang kedalam filtrat hasil penyaringan I dengan rasio yang sama yaitu 1 gram abu batang pisang/ $25 \mathrm{ml}$. Diamkan selama 3 hari. Saring dengan kertas saring kemudian ukur volume filtrat alkali lalu ambil $20 \mathrm{ml}$ dari ekstrak yang diperoleh untuk dianalisa normalitasnya. Tambahkan abu batang pisang kedalam filtrat hasil penyaringan II dengan rasio yang sama yaitu 1 gram abu batang pisang/ $25 \mathrm{ml}$. Diamkan selama 3 hari. Saring dengan kertas saring kemudian ukur volume filtrat alkali lalu ambil $20 \mathrm{ml}$ dari ekstrak yang diperoleh untuk dianalisa normalitasnya. Percobaan ini dihentikan sampai normalitas ekstrak alkali telah konstan. Dilakukan perlakuan yang sama dengan variasi rasio 2 gram abu batang pisang/ $25 \mathrm{ml} ; 3$ gram abu batang pisang/ $25 \mathrm{ml}$; dan 4 gram abu batang pisang/ $25 \mathrm{ml}$.

\section{Hasil Dan Pembahasan Hasil Penelitian}

Pemanfaatan batang pisang sebagai sumber alkali dapat dilakukan dengan 3 tahapan, yang pertama ialah pengurangan kadar air batang pisang, kedua proses pirolisis (pengabuan) batang pisang dengan menggunakan muffle furnace, dan yang ketiga proses ekstraksi abu batang pisang.

\section{Kadar Air dan Kadar Abu Batang Pisang}

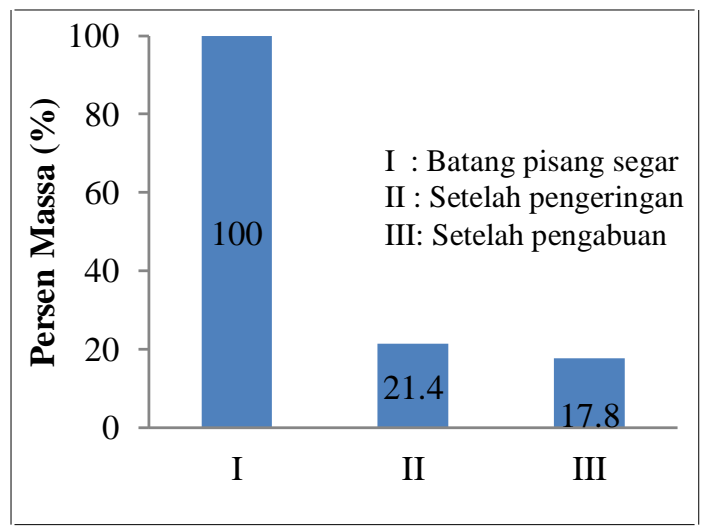

Gambar 2. Persen Penurunan Massa Sampel

Gambar 2 menunjukkan grafik penurunan massa batang pisang pada saat preparasi bahan baku. Pada bagian I (batang pisang segar) massa batang pisang awalnya sebesar $100 \%$ dengan basis perhitungan 500 gram. Kemudian dilakukan proses pengeringan untuk menurunkan kadar air pada sampel. Dimana batang pisang basah dikeringkan dibawah sinar matahari selama 7 hari. Pada bagian II (batang pisang setelah pengeringan), hasil pengeringan batang pisang menurunkan kadar air pada sampel hingga 78,6 \% dari berat awal. Sehingga massa batang pisang menjadi 107 gram (sekitar 21,4 \%). Pada bagian III (batang pisang setelah pengabuan) menunjukkan sisa massa dari proses pirolisis batang pisang, hasil pirolisis menghilangkan kandungan anorganik dari sampel yang menyisakan abu. Kandungan abu dari batang pisang dari hasil percobaan diperoleh sebesar 17,8 $\%$. 


\section{Kandungan Mineral Abu Batang Pisang}

Batang pisang yang sudah kering dipotong kecil-kecil sebanyak 50 gram dan pirolisis dengan menggunakan muffle furnace pada temperatur pembakaran $550{ }^{\circ} \mathrm{C}$ selama 3 jam. Hasil pirolisis batang pisang menyisakan abu sebanyak $17,4 \%$ dari berat awal.

Abu hasil pembakaran dianalisa menggunakan analisa SEM-EDX untuk mengetahui komponen yang terkandung dalam abu batang pisang tersebut. Hasil yang diperoleh dari analisa ini dapat dilihat pada tabel berikut:

Tabel 1. Komponen Mineral Abu Batang Pisang

\begin{tabular}{|l|c|}
\hline \multicolumn{1}{|c|}{ Komponen } & Persen Berat (\%) \\
\hline Karbon (C) & 10,03 \\
Oksigen (O) & 15,45 \\
Nikel (Ni) & 9,12 \\
Besi (Fe) & 2,00 \\
Kalium (K) & 36,19 \\
Natrium (Na) & 13,99 \\
Silikon (Si) & 1,04 \\
\hline
\end{tabular}

Dari Tabel 1 diatas dapat dilihat bahwa kandungan kalium yang terdapat pada abu batang pisang sebesar $36,99 \%$.

Pengaruh Waktu terhadap Normalitas (N) Ekstrak Alkali Maserasi Semibatch pada Rasio (Abu Batang Pisang/ Pelarut) yang Divariasikan

Berikut adalah grafik yang menunjukkan perubahan normalitas ekstrak alkali dari hasil penyamplingan maserasi semibatch. Untuk proses secara semibatch dilakukan penyamplingan ekstrak abu setiap 12 jam sekali dan filtratnya dianalisa. Penyamplingan dihentikan sampai konsentrasi ekstrak konstan (mencapai titik jenuh). Analisa filtrat menggunakan metode titrasi menggunakan $\mathrm{HCl}$ (Asam Klorida) sebagai pentiter untuk mengetahui konsentrasi basa yang dikandung dari hasil maserasi.

Dari Gambar 3 dapat dilihat bahwa semakin lama waktu maserasi maka semakin meningkat normalitas ektrak alkali. Pemberian waktu kontak antara pelarut dan bahan yang diekstrak sangat perlu. Kenaikan konsentrasi menjukkan bahwa terjadinya proses difusi alkali pada pelarut. Hal ini menunjukkan semakin besar jumlah padatan yang akan diserap maka waktu ekstraksi akan semakin lama [5].

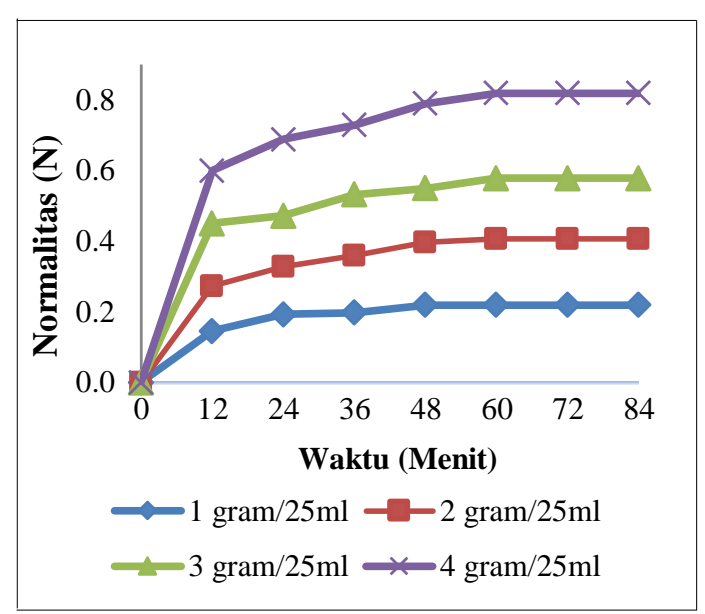

Gambar 3. Grafik Pengaruh Waktu terhadap Normalitas (N) Ekstrak Alkali Maserasi Semibatch pada Rasio (Abu Batang Pisang/ Pelarut) yang Divariasikan

Washing time merupakan waktu yang dibutuhkan oleh pelarut mengeluarkan senyawa yang terdapat dalam sel. Pelarut akan berhenti menarik senyawa jika keadaan pelarut sudah jenuh dan tidak lagi memiliki perbedaan konsentrasi [2]. Dari Gambar 3 diperoleh nilai washing time dari maserasi semibatch pada rasio 1 gram/ $25 \mathrm{ml}$ sebesar 60 jam sedangkan untuk rasio $2 \mathrm{gram} / 25 \mathrm{ml} ; 3 \mathrm{gram} / 25 \mathrm{ml}$; dan $4 \mathrm{gram} /$ $25 \mathrm{ml}$ sebesar 72 jam. Nilai ini diperoleh dari waktu pertama kali ektrak memiliki nilai normalitas konstan. Berdasarkan hasil percobaan, untuk maserasi secara semibatch nilai washing time rata-rata yang diperoleh pada setiap rasio adalah selama 72 jam (3 hari).

Pengaruh Waktu terhadap Normalitas (N) Ekstrak Alkali Maserasi Batch pada Rasio (Abu Batang Pisang/ Pelarut) yang Divariasikan

Tujuan dari maserasi batch ini untuk menentukan besar normalitas ekstrak alkali mengalami kondisi jenuh (normalitas ekstrak konstan) yang merupakan kondisi jenuhnya pelarut. Gambar 4 menunjukkan grafik pengaruh waktu pergantian padatan terhadap normalitas ekstrak alkali abu yang dihasilkan. Penambahan waktu kontak antara pelarut dan abu yang diekstrak sangat perlu. Kenaikan konsentrasi pada proses ini menunjukkan bahwa masih terjadi proses difusi alkali pada pelarut. Berikut adalah grafik yang menunjukkan perubahan normalitas ekstrak alkali dari hasil maserasi batch. 


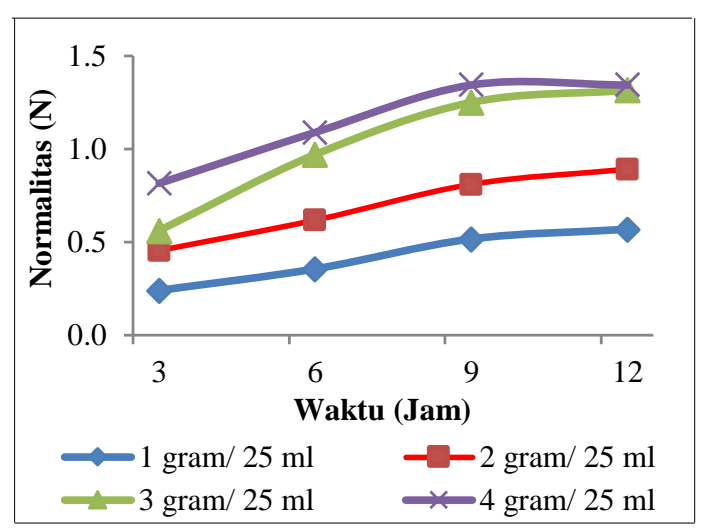

Gambar 4. Grafik Pengaruh Waktu terhadap Normalitas (N) Ekstrak Alkali Maserasi Batch pada Rasio (Abu Batang Pisang/ Pelarut) yang Divariasikan

Setelah melakukan percobaan maserasi semibatch dan batch diperoleh perbedaan nilai normalitas ekstrak alkali. Dimana pada rasio berturut-turut sebesar $1 \mathrm{gram} / 25 \mathrm{ml} ; 2 \mathrm{gram} / 25$ $\mathrm{ml} ; 3 \mathrm{gram} / 25 \mathrm{ml}$; dan $4 \mathrm{gram} / 25 \mathrm{ml}$ masingmasing memiliki nilai normalitas yang masih mengalami kenaikan dari 0,219 $\mathrm{N}$ menjadi 0,567 $\mathrm{N} ; 0,407 \mathrm{~N}$ menjadi $0,891 \mathrm{~N} ; 0,578 \mathrm{~N}$ menjadi $1,315 \mathrm{~N}$; dan $0,819 \mathrm{~N}$ menjadi $1,345 \mathrm{~N}$. Hal ini menunjukkan bahwa proses maserasi masih tetap berlangsung selama pelarut masih belum mencapai kondisi jenuh (konsentrasi alkali pada abu dan pelarut mengalami kondisi setimbang).

\section{Pengaruh Waktu terhadap pH Ekstrak Alkali Maserasi Semibatch pada Rasio (Abu Batang Pisang/ Pelarut) yang Divariasikan}

Berikut adalah grafik yang menunjukkan perubahan $\mathrm{pH}$ ekstrak alkali dari hasil penyamplingan maserasi semibatch.

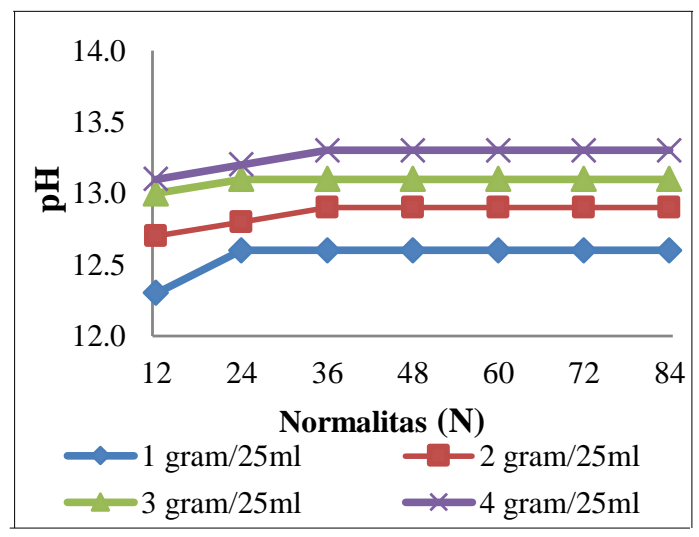

Gambar 5. Grafik Pengaruh Waktu terhadap pH Ekstrak Alkali Maserasi Semibatch pada Rasio (Abu Batang Pisang/ Pelarut) yang Divariasikan

Analisa pH ekstrak alkali pada percobaan ini bertujuan untuk mengidentifikasi ada atau tidaknya kandungan basa dalam larutan. Dari Gambar 5 dapat dilihat bahwa semakin lama waktu maserasi dan semakin besar rasio abu maka $\mathrm{pH}$ ekstrak akan semakin meningkat. Hal ini disebabkan oleh alkali $\left(\mathrm{K}_{2} \mathrm{O}\right.$ atau $\left.\mathrm{Na}_{2} \mathrm{O}\right)$ yang terkandung pada abu saat bereaksi dengan pelarut aquadest akan menghasilkan kalium hidroksida $(\mathrm{KOH})$ ataupun natrium hidroksida $(\mathrm{NaOH})$ yang bersifat basa [6].

Berdasarkan hasil percobaan, untuk maserasi secara semibatch diperoleh $\mathrm{pH}$ ekstrak alkali bernilai konstan pada rasio $1 \mathrm{gram} / 25 \mathrm{ml}$; $2 \mathrm{gram} / 25 \mathrm{ml} ; 3 \mathrm{gram} / 25 \mathrm{ml}$; dan 4 gram/ $25 \mathrm{ml}$ masing-masing sebesar 12,6; 12,9; 13,1; dan 13,3.

Pengaruh Waktu terhadap pH Ekstrak Alkali Maserasi Batch pada Rasio (Abu Batang Pisang/ Pelarut) yang Divariasikan

Berikut adalah grafik yang menunjukkan perubahan $\mathrm{pH}$ ekstrak alkali dari hasil maserasi batch.

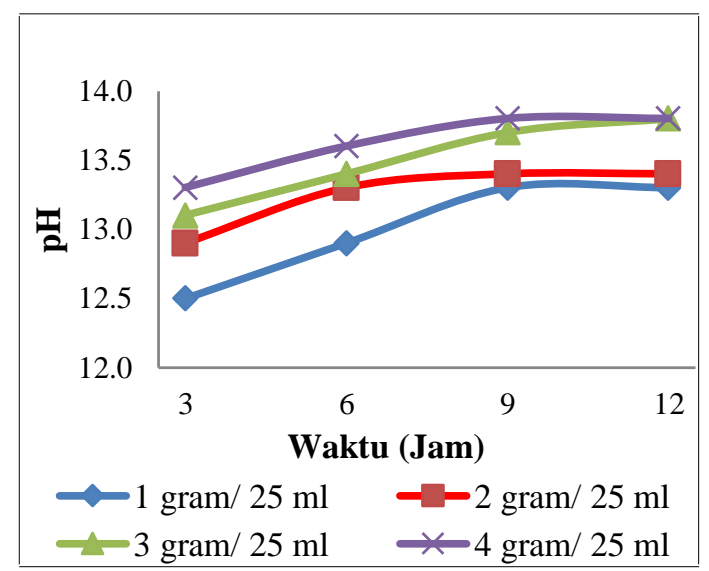

Gambar 6. Grafik Pengaruh Waktu terhadap pH Ekstrak Alkali Maserasi Batch pada Rasio (Abu Batang Pisang/ Pelarut) yang Divariasikan

Berdasarkan hasil percobaan, untuk maserasi secara batch diperoleh waktu pH ekstrak alkali bernilai konstan selama 9 hari. Sehingga kandungan alkali pada ekstrak semakin tinggi.

Setelah melakukan percobaan maserasi semibatch dan batch diperoleh perbedaan nilai $\mathrm{pH}$ ekstrak alkali. Dimana pada rasio berturut-turut sebesar $1 \mathrm{gram} / 25 \mathrm{ml} ; 2 \mathrm{gram} / 25 \mathrm{ml}$; $3 \mathrm{gram} / 25$ $\mathrm{ml}$; dan 4 gram/ $25 \mathrm{ml}$ masing-masing memiliki nilai $\mathrm{pH}$ yang masih mengalami kenaikan dari 12,6 menjadi 13,$3 ; 12,9$ menjadi 13,$4 ; 13,1$ menjadi 13,8; dan 13,3 menjadi 13,8. Hal ini menunjukkan bahwa kandungan ekstrak alkali pada hasil maserasi batch lebih besar dari pada hasil maserasi semibatch. Karena semakin besar kandungan alkali pada ekstrak maka nilai $\mathrm{pH}$ juga akan semakin tinggi.

Hubungan pH dengan Normalitas (N) Ekstrak Alkali Abu pada Maserasi Semibatch 
Berikut grafik yang menunjukkan hubungan $\mathrm{pH}$ dan normalitas (N) ekstrak alkali pada berbagai rasio.

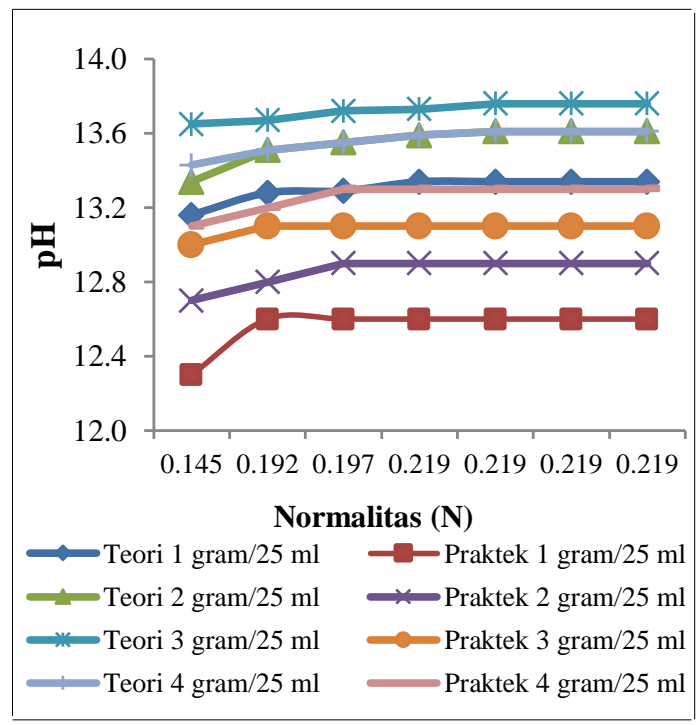

Gambar 7. Grafik Hubungan pH dengan Normalitas (N) Ekstrak Alkali Abu pada Maserasi Semibatch

Nilai teori yang ada pada grafik diperoleh dari hasil titrasi ekstrak alkali, sedangkan nilai praktek yang ada pada grafik diperoleh dari hasil pengukuran $\mathrm{pH}$ meter ekstrak alkali. Nilai $\mathrm{pH}$ dan normalitas saling berkaitan satu sama lain. Semakin tinggi normalitas ekstrak alkali maka semakin tinggi pula $\mathrm{pH}$ larutannya. Penentuan kadar alkali pada ekstrak dapat dilihat dari nilai normalitas ataupun nilai pH-nya dengan menggunakan persamaan berikut [6]:

$$
\mathrm{pH}+\mathrm{pOH}=14
$$

Dari hasil percobaan yang telah dilakukan, dengan membandingkan hasil analisa secara teori dan praktek masih terdapat perbedaan hasil perolehan kadar alkali. Adapun ralat yang diperoleh dari perbandingan nilai teori dan praktek untuk rasio berturut-turut sebesar $1 \mathrm{gram} /$ $25 \mathrm{ml} ; 2 \mathrm{gram} / 25 \mathrm{ml} ; 3 \mathrm{gram} / 25 \mathrm{ml}$; dan 4 gram/ $25 \mathrm{ml}$ masing-masing memiliki ralat sebesar 5,57 $\% ; 5,08 \% ; 4,03 \%$; dan 2,22\%.

\section{Hubungan pH dengan Normalitas (N) Ekstrak Alkali Abu pada Maserasi Batch}

Dari hasil percobaan yang telah dilakukan telah sesuai dengan teori, yaitu nilai $\mathrm{pH}$ ekstrak alkali meningkat seiring dengan bertambahnya nilai normalitas ekstrak alkali. Namun terdapat perbedaan hasil perolehan kadar alkali secara teori dan praktek. Adapun ralat yang diperoleh dari perbandingan nilai teori dan praktek untuk rasio berturut-turut sebesar $1 \mathrm{gram} / 25 \mathrm{ml} ; 2$ gram/ $25 \mathrm{ml} ; 3 \mathrm{gram} / 25 \mathrm{ml} ; 4 \mathrm{gram} / 25 \mathrm{ml}$; dan rasio berubah masing-masing memiliki ralat sebesar $4,00 \% ; 3,85 \% ; 1,43 \% ; 1,84 \%$; dan 3,65\%.

Berikut grafik yang menunjukkan hubungan $\mathrm{pH}$ dan normalitas (N) ekstrak alkali pada berbagai rasio.

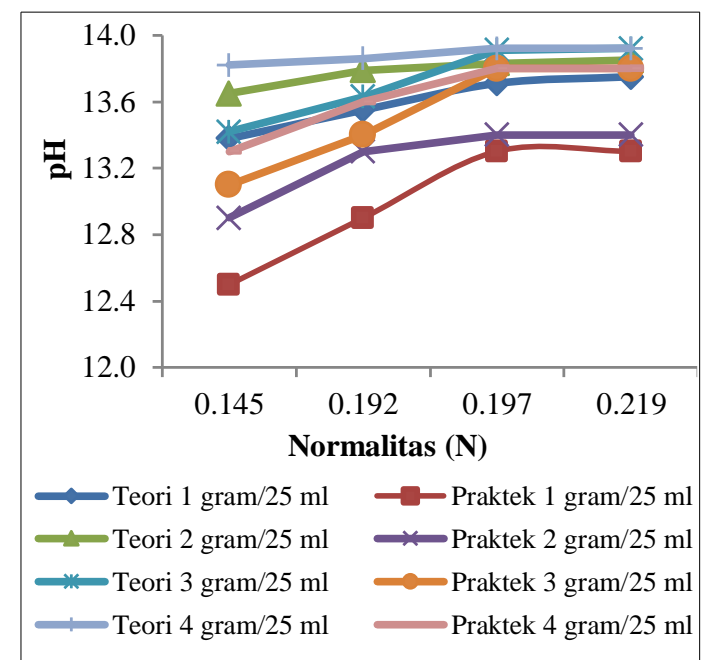

Gambar 8. Grafik Hubungan pH dengan Normalitas (N) Ekstrak Alkali Abu pada Maserasi Batch

Pengaruh Rasio (Abu Dengan Pelarut) Terhadap Rendemen Alkali (\%)

Distribusi pelarut ke padatan akan sangat berpengaruh pada perolehan rendemen alkali [8]. Pada variasi rasio 1 gram/ $25 \mathrm{ml} ; 2$ gram/ $25 \mathrm{ml}$; 3 gram/ $25 \mathrm{ml}$; dan 4 gram/ $25 \mathrm{ml}$ diperoleh rendemen abu masing-masing sebesar 52,37 \%; 47,47\%; 46,07\%; dan 45,96\%. Berikut adalah grafik yang menunjukkan pengaruh rasio (abu batang pisang dengan pelarut) terhadap rendemen alkali.

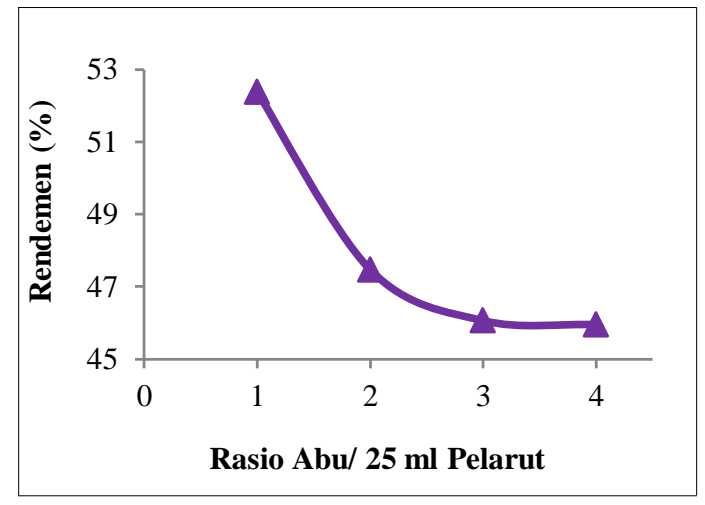

Gambar 9. Grafik Pengaruh Rasio (Abu Dengan Pelarut) Terhadap Rendemen Alkali (\%)

Penyebab menurunnya rendemen alkali pada penambahan jumlah rasio (abu batang pisang/ pelarut) disebabkan oleh penjelasan pada teori sebelumnya yaitu kecilnya luas kontak antara pelarut dan abu sehingga distribusi pelarut ke abu batang pisang tidak merata dan komponen 
alkali pada abu batang pisang tidak terekstrak sempurna.

\section{Kesimpulan}

Kesimpulan yang diperoleh dari penelitian ini adalah:

1. Batang pisang berpotensi dijadikan sebagai sumber alkali. Kandungan kalium $\left(\mathrm{K}_{2} \mathrm{O}\right)$ dan natrium $\left(\mathrm{Na}_{2} \mathrm{O}\right)$ pada abu batang pisang masing-masing sebesar $36,19 \%$ dan $13,99 \%$.

2. Kadar air dan rendemen abu batang pisang masing-masing sebesar 78,6\% dan 17,7\%.

3. Washing time (waktu pelarut jenuh) untuk sistem semibatch diperoleh waktu selama 72 jam (3 hari). Sedangkan untuk sitem batch diperoleh waktu selama 12 hari.

4. Normalitas ekstrak alkali pada percobaan maserasi semibatch dan batch. Dimana pada rasio berturut-turut sebesar $1 \mathrm{gram} / 25 \mathrm{ml} ; 2$ gram/ $25 \mathrm{ml} ; 3$ gram/ $25 \mathrm{ml}$; dan 4 gram/ 25 $\mathrm{ml}$ masing-masing memiliki nilai normalitas yang masih mengalami kenaikan dari 0,219 N menjadi $0,567 \mathrm{~N}$; $0,407 \mathrm{~N}$ menjadi $0,891 \mathrm{~N}$; $0,578 \mathrm{~N}$ menjadi $1,315 \mathrm{~N}$; dan $0,819 \mathrm{~N}$ menjadi $1,345 \mathrm{~N}$.

5. Rendemen alkali terserap tertinggi diperoleh pada rasio (pelarut/padatan) $1 \mathrm{gram} / 25 \mathrm{ml}$ yaitu sebesar 52,37\%.

\section{Daftar Pustaka}

[1] A. Apriantono, D. Fardian, Analisa Pangan, Departemen Pendidikan dan Kebudayaan, Dirjen Pendidikan Tinggi PAU Pangan dan Gizi IPB: Bandung, 1989.

[2] D. L. Fauzannah, Perbandingan Metode Maserasi, Remaserasi, Perkolasi, dan Reperkolasi terhadap Rendemen Ekstrak Temulawak (Curcuma xanthorrhiza Roxb), Skripsi, Fakultas Teknologi Pertanian, Institut Pertanian Bogor, 2010.

[3] D. Mohapatra, Mishra, Sabyasachi, dan N. Sutar, Banana and its By-Produk Utilisation: an Overview, Journal of Scientific \& industrial Reasearch, Vol 69 (2010) 323329.

[4] E. A. Ramadhan dan Phaz, H. Aprival, Pengaruh Konsentrasi Etanol, Suhu dan Jumlah Stage Pada Ekstraksi Oleoresin Jahe (Zingiber Officinale Rosc) Secara Batch, Skripsi, Teknik Kimia, Fakultas Teknik, Universitas Diponegoro, 2010.

[5] F. Diantika, Sutan, S. Malin; dan Yulianingsih, Effect of Long Extraction and Concentration and Concentration of Ethanol Solvent Extraction Antioxidant Cocoa Bean (Theobroma caca L.) Jurnal Teknologi Pertanian, Vol.15, No.3 (2014) 159-164.
[6] Fessenden, J. Ralph, dan J.S. Fessenden, Kimia Organik. Edisi Kedua. Jilid 1. Penerbit: Erlangga. 1982.

[7] Istiqomah, Perbandingan Metode Ekstraksi Maserasi dan Sokletasi terhadap Kadar Piperin Buah Cabe Jawa (Piperis retrofracti fructus), Skripsi, Program Studi Farmasi, Fakultas Kedokteran dan Ilmu Kesehatan, Universitas Islam Negeri Syarif Hidayatullah, Jakarta, 2013.

[8] Jayanudin, Lestrari, A. Zakiyah, dan F. Nurbayanti, Pengaruh Suhu dan Rasio Pelarut Ekstraksi terhadap Rendemen dan Viskositas Natrium Alginat dari Rumput Laut Cokelat (Sargassum sp), Jurnal Integrasi Proses, Vol.5, No.1 (2014) 51-55

[9] Kuntari, Aprilita, N. Hidayat; dan Suherman, Utilization of Coal Bottom Ash a Low-Cost Adsorbent for the Removal Acid Red 114 Dye, Journal Ilmu-ilmu MIPA, ISSN: 1411-1047. 2009.

[10] N. Nopriantina, dan Astuti, Pengaruh Ketebalan Serat Batang Pisang Kepok (Musa paradisiaca) terhadap Sifat Mekanik Material Komposit Poliester Serat Alam, Jurnal Fisika UNAND, Vol.2, No.3 (2013) 195-203. ISSN : 2302-8491

[11] S. Anwar, Pemanfaatan Serat Batang Pohon Pisang dalam Sistesis Material Hibrida berbasis Geopolimer Abu Layang Batubara, Skripsi, Jurusan Kimia, Fakultas Matematika dan Ilmu Pengetahuan Alam, Universitas Negeri Semarang, 2015.

[12] U. B. Surono, Peningkatan Kualitas Pembakaran Biomassa Limbah Tongkol Jagung sebagai Bahan Bakar Alternatif dengan Proses Karbonisasi dan Pembriketan, Jurnal Rekayasa Proses, Vol 4, No. 1 (2010) 13-18. 